\title{
MAciew
}

\section{The Geography of Strain: Organizational Resilience as a Function of Intergroup Relations}

\begin{tabular}{|r|l|}
\hline Journal: & Academy of Management Review \\
\hline Manuscript ID & AMR-2016-0004-Original.R3 \\
\hline Kanuscript Type: & Original Manuscript \\
\hline Keywords: & Organizational Psychology, Relationships, Emotions \\
\hline Abstract: & $\begin{array}{l}\text { Organizational resilience is defined as the organization's ability to absorb } \\
\text { strain and preserve or improve functioning despite the presence of } \\
\text { adversity. Existing scholarship implicitly assumes that organizations } \\
\text { experience and respond holistically to acute forms of adversity. We } \\
\text { challenge this assumption by theorizing how adversity can create } \\
\text { differential strain, affecting parts rather than the whole of } \\
\text { ofganizations. We argue that relations among those parts fundamentally } \\
\text { shape organizational resilience. We develop a theoretical model that maps } \\
\text { how the differentiated emergence of strain in focal parts of an organization } \\
\text { triggers the movements of adjoining parts to provide or withhold resources } \\
\text { necessary for focal parts to adapt effectively. Drawing on core principles of } \\
\text { theories about intergroup relations, we theorize three specific pathways- } \\
\text { integration, disavowal, and reclamation-by which responses of adjoining } \\
\text { parts to focal part strain shape organizational resilience. We further } \\
\text { theorize influences on whether and when adjoining parts are likely to select } \\
\text { different pathways. The resulting theory reveals how the social processes } \\
\text { among parts of organizations influence member responses to adversity, } \\
\text { and ultimately organizational resilience. We conclude by noting the } \\
\text { implications for organizational resilience theory, research and practice. }\end{array}$ \\
\hline
\end{tabular}


The Geography of Strain:

Organizational Resilience as a Function of Intergroup Relations

\author{
William A. Kahn, Boston University, wkahn@bu.edu \\ Michelle A. Barton, Boston University, mbarton@bu.edu \\ Colin M. Fisher, University College London, colin.fisher@ucl.ac.uk \\ Emily D. Heaphy, University of Rhode Island, eheaphy@uri.edu \\ Erin M. Reid, McMaster University, reidem@mcmaster.ca \\ Elizabeth D. Rouse, Boston University, rouse@,bu.edu
}

\begin{abstract}
Acknowledgement: For their insightful comments and constructive feedback, we thank associate editor Gary Ballinger and the reviewers. We also wish to note that after the first author, the order of authorship is alphabetical, representing the co-authors' equal contributions to this article.
\end{abstract}




\begin{abstract}
Organizational resilience is defined as the organization's ability to absorb strain and preserve or improve functioning despite the presence of adversity. Existing scholarship implicitly assumes that organizations experience and respond holistically to acute forms of adversity. We challenge this assumption by theorizing how adversity can create differential strain, affecting parts rather than the whole of organizations. We argue that relations among those parts fundamentally shape organizational resilience. We develop a theoretical model that maps how the differentiated emergence of strain in focal parts of an organization triggers the movements of adjoining parts to provide or withhold resources necessary for focal parts to adapt effectively. Drawing on core principles of theories about intergroup relations, we theorize three specific pathways-integration, disavowal, and reclamation — by which responses of adjoining parts to focal part strain shape organizational resilience. We further theorize influences on whether and when adjoining parts are likely to select different pathways. The resulting theory reveals how the social processes among parts of organizations influence member responses to adversity, and ultimately organizational resilience. We conclude by noting the implications for organizational resilience theory, research and practice.
\end{abstract}


Organizational resilience is defined as the organization's ability to absorb strain and preserve or improve functioning despite the presence of adversity (Sutcliffe \& Vogus, 2003). Existing research typically portrays the resilience of collectives-groups, organizations, and communities — as anchored in the collective processing of information about environmental perturbations, system properties and capabilities, deviations from operating parameters, and resource constraints and needs. The resilient organization possesses a collective "intelligent wariness" (Reason, 1997); an "organizational intelligence" gathers and analyzes realistic information by which to comprehend complex situations (Catino \& Patriotta, 2013). The guiding premise is that the organization-as-awhole is the key entity, the center through which information is processed and decisions are made about how to create and divert resources to cope with unexpected situations (Sutcliffe \& Vogus, 2003) and control unwanted variability (Madni \& Jackson, 2009).

This theoretical portrait, however, does not align with a certain reality of what often occurs in organizations: adversity affects and is responded to not by the organization-as-a-whole but by that part of the organization in which it is most directly located (Horne \& Orr, 1998). When full-blown crises, natural disasters, and destructive attacks occur, they engage the organization-as-a-whole, rallying members all at once to face existential threats (James \& Wooten, 2010; McFarlane \& Norris, 2006) and support one another (Dutton, Worline, Frost, \& Lilius, 2006; Powley, 2009). Yet such events are rare; more common are mounting demands that threaten to overwhelm capacities (Williams, Gruber, Sutcliffe, Shepherd \& Zhao, 2017; Woods \& Wreathall, 2008). In such cases, we argue, the primary actor is not the organization-as-a-whole but its partsgroups, teams, functions, departments, and hierarchical levels. Hollnagel and Woods 
(2006) note the need for such a focus when they write that there is "ample practical experience to show that some parts of an organization may be safe while others may be unsafe. The safety of an organization ... depends on the ways in which they [the parts] are coupled and how coordination across the parts is fragmented or synchronized (p.354)." What scholars have not yet conceptualized is how such fragmentation or synchronization occurs during sustained adversity and shapes organizational resilience.

We start from the assumption that sustained adversity can trigger strain that gets localized, as specific parts of organizations experience excessive demands on capabilities that, unmitigated, can lead to impaired performance (Woods, 2006); and that localized strain differentiates parts of organizations. In making this assumption, we challenge an underlying premise within existing scholarship on organizational resilience: that the organization-as-a-whole is the primary actor when dealing with adversity. We believe that attention to the "geography of strain" is critical to understand, as under certain types of adversity, strain appears locally and weakens particular parts in ways that diminish organizational capabilities. Defining organizational resilience solely in terms of the organization-as-a-whole risks framing and treating strain as an isolated problem and ignoring the broader implications to organizational functioning and resilience of how strain is experienced and managed. In other words, unmitigated strain that emerges in a part of an organization can, over time, impair the performance of the organization itself.

The focus on relations among parts of organizations has the potential to reframe how managers can enable organizational resilience. First, when resilience is theorized as rebounding from crises, managers tend to look for dramatic cues that signal assaults on the whole organization. Theorizing resilience in terms of strain that appears relatively 
slowly, in a part of the organization, enables managers to attend to weaker cues such as increasing gaps in performance or mounting distress among members; such cues signal operational breakdowns that can spread across time and space and leave the organization vulnerable to crisis. Second, when resilience is conceptualized in terms of the whole organization, the strains that emerge in specific parts risk being treated as only local problems. When managers are better attuned to the significance of relations among parts, they are more likely to see the problems of "other" parts as important to them as well and act accordingly. Third, when resilience is thought to be located in the organization-as-awhole, managers will pay close attention to the signals emanating from senior leaders rather than to strain accumulating at the front lines of organizations. They are less likely to map for themselves the emerging geography of strain, which ought to dictate their responses to adversity. Thus, in theorizing the impact of differentiated strain on parts of organizations, we offer managers more tools to enable resilient organizations.

To enable this reframing, we develop a theoretical process model that maps dynamics and pathways triggered by the emergence of differentiated strain in specific parts of organizations. That adversity sets in motion the choices of unaffected parts to provide or withhold important resources that can help affected parts adapt effectively. We delineate three pathways - integration, disavowal, and reclamation - triggered by those choices. Drawing on social identity theory (Tajfel \& Turner, 1979; Turner, 1975) and its elaborations about intergroup relations (Alderfer, 1987; Ashforth \& Mael, 1989; Hogg, van Knippenberg \& Rast, 2012), we offer a nuanced view of how in-group and out-group dynamics affect the responses of parts of organizations and the implications for 
organizational resilience. Further, we explain the influences on why those responses emerge and dictate different sequences in organizations.

Our theorizing offers three primary contributions to organizational resilience scholarship. First, we introduce the geography of strain. We follow how differentiated strain fragments organizations into affected and unaffected parts, which move together and apart in ways that ultimately shape organizational resilience. Second, we use concepts from theories of intergroup relations to describe three pathways through which unaffected parts react to accumulating strain in affected parts. These pathways reveal how social processes influence organizational responses to adversity, and ultimately, resilience. We also explain why organizational parts respond in particular ways and traverse these pathways. Third, we incorporate temporal aspects into theorizing organizational resilience. We make explicit how relations among differentiated parts unfold over time, which itself becomes a key contributor or inhibitor of resilience.

\section{REIMAGINING ORGANIZATIONAL RESILIENCE}

Differentiated strain and its effects can be seen across various organizations. Consider the hospital emergency department (ED). The ED exists at the boundary of patient demand and hospital services; it can easily become the overcrowded way station for patients who, for lack of appropriate hospital resources, wait for triage, testing and evaluation, handoffs, and discharge or admitting. As they wait, more patients arrive, varying in the severity of ailments. The ED becomes overcrowded, as patient demand exceeds available space, staffing, and diagnostic technologies. Such overcrowding sets in motion a series of events described by Wears and colleagues (Wears \& Perry, 2006; Wears, Perry, Anders, \& Woods, 2008). As patient demand increases, ED shifts medical 
staff between trauma, pediatric, severe and mild illness rooms as needed. The accumulation of critically ill patients forces ED members to now treat some patients and not others, re-purpose closet spaces, and place able patients in chairs rather than gurneys. With mounting demand and the lack of additional resources, the ED can enter "free-fall:" staff members are able only to track patients and offer medical care only to those in immediate danger. Other parts of the hospital (i.e., radiology, labs, inpatient floors, consulting services, senior hospital leaders) remain largely unaware or unconcerned with what is occurring in the ED.

This process of ED degradation plays out over time rather than as a catastrophic event, such as a neighborhood fire that sends dozens to the hospital. Demand can slowly accumulate from exogenous forces, such as the closure of community psychiatric hospitals that leave patients increasingly using the ED for mental health needs (Hoot \& Aronsky, 2008). As more mental health patients turn to the ED (aided by local police at a loss as to where else to take them), the ED becomes, over weeks and months, a system under mounting pressure. Left to its own devices amidst accumulating demand, the ED would pass through various states of functioning (see Hollnagel \& Sundstrom, 2006; Wears, et. al., 2008). The unit would shift from typical functioning (i.e., usual solutions to deal with usual problems without system degradation) to regular reduced functioning (i.e., adaptations consume buffering capacity, chronically degrading the ability to absorb sudden disruptions). As the number of patients grows, the ED would shift to irregular reduced functioning (i.e., attempts to develop compensatory buffers to manage disturbances), and later, to disturbed functioning (i.e., using novel and highly irregular resources to maintain operations). Ultimately, ED "free fall” would mean discontinuing 
operations for all but the most critical patients. The ED has become "brittle:" significant gaps in the continuity of effective care threaten patient safety, engender possible crises, and diminish hospital effectiveness (Nemeth, Wears, Woods, Hollnagel, \& Cook, 2008).

Existing theory is unlikely to frame this scenario in terms of organizational resilience. Yet this scenario highlights the boundary conditions for our reimagining and theorizing organizational resilience. First, strain emerges in a particular part of an organization over time, distinguishing that part from other, relatively unaffected parts. Second, the strain in that part accumulates as mounting demand for services are placed upon front line staff. Third, the affected part's accumulating strain is at least partly amenable to relief from other parts, which could provide resources to lessen demand, increase capacity, or share the burden. These boundary conditions are relatively common at the front lines of organizations that serve clients, customers, and patients. Similar to the ED, the capacities of TSA airport security can become severely strained, as airport construction or the addition of new airlines place immense pressure on TSA workers. The call centers and field workers of local electrical utilities can come under fire from customers and media for a series of outages caused by the prolonged replacement of equipment and technology. The accumulation of opioid-related crimes can severely overwhelm the caseloads of social workers entrusted with the welfare of increasing numbers of children placed at greater risk by families severely disturbed by opioidrelated deaths and incarcerations. In each case, the front lines are pushed to the edge of effective functioning by exogenous situations unfolding over time.

Organizational scholars are likely to conceptualize these situations in terms of operational difficulties (Kantur \& Isein-Say, 2012; Madni \& Jackson, 2009). The front 
lines lack appropriate resources, do not operate efficiently, or are powerless to stem demand or force others to provide relief. These explanations are reasonable. Yet they do not admit the possibility that front line struggles signal problems for the resilience of the organization itself. The mounting strain of the front lines would scarcely register in most organizational resilience frameworks (for exceptions, see Woods \& Branlat, 2011; Woods \& Wreathall, 2008). If they did register, responses would likely involve aggregating the thoughts and behaviors of front line staff to inform collective efforts to synthesize intelligence and improvise shared solutions (Madni \& Jackson, 2009; Powley, 2009; Westrum, 2006). This too is reasonable. Yet it misses a crucial point: what happens between groups is crucial to understanding and enabling organizational resilience. To explore this more fully, we introduce two conceptual frames integral to our theory building: creeping strain, and intergroup facets of organizational resilience.

\section{Creeping Strain}

Relations between parts comes into sharp relief when we consider how adversity emanates not simply from catastrophic errors, scandals, crises, and disasters (Meyer, 1982; Vogus \& Sutcliffe, 2007) but from challenging risks, stresses, and disruptions of routines (Boin \& McConnell, 2007; Woods, 2006). Both types of adversity involve strain. They diverge in terms of how and where strain manifests and unfolds. In crises, the organization-as-a-whole itself is quickly understood as under assault; members across the organization mobilize to reduce collective strain and recover operations (Meyer, 1982; McFarlane \& Norris, 2006; Pearson \& Clair, 1998). The synchronization that occurs among the different parts of an affected organization to protect, defend, and maintain operations is expansive, obvious, and relatively fast. In less startling 
circumstances, adversity can present much differently, as unfolding situations cause strain in only some parts of an organization (Boin \& Van Eeten, 2013). When members perceive strain as belonging to those parts, rather than to the organization itself, synchronization becomes a different matter not yet theorized in organizational resilience.

We anchor our theorizing efforts with an understanding of a specific category of adversity likely to target parts of organizations. "Creeping developments" are complex, emergent, and interactive processes that lead to adverse situations (Cunha, Clegg \& Kamoche, 2006). Unlike sudden events, these developments unfold over time, as expected issues mount and interact in ways that form unexpected processes that expand in scope (Cunha, et. al., 2006). We suggest that creeping strain-defined as the gradual development of situations that stretch a group's resources to the point of impairmentmanifests in the more clearly exposed parts of organizations, such as the hospital's ED or the utility's customer service call centers or field representatives. These parts are typically front lines, located at the boundary between organizations and external constituencies (Kinman, 2009), where members are regularly subject to potentially overwhelming non-novel demands (Woods, 2006). This includes, for example, the accumulation of airport passengers at security lines, leaving TSA workers to deal with irate passengers frustrated by long wait times. Or the mounting opioid-related family problems that confront child welfare agency social workers with gradually expanding caseloads. Creeping strain that remains unmitigated and isolated within front lines creates a metaphorical "geography:" strain is located within focal parts, on the periphery of which sit unaffected adjoining parts, i.e., ancillary groups or teams, business units, functions, or hierarchical levels. 
The focus on creeping strain reveals processes of organizational resilience that otherwise go unnoticed. Definitions of organizational resilience emphasize the absorption of strain (Sutcliffe \& Vogus, 2003) by which people and systems accommodate variability and preserve stability (Wildavsky, 1991). How strain is absorbed and variability is accommodated, however, is often ignored when scholars focus on how organizations "bounce back" from adversity, i.e., how they recover and heal from ruptures that created pathology (Bonanno, 2004). That more typical focus underplays how resilience consists of people's abilities to maintain stable equilibrium even as they experience transient perturbations in normal functioning (Bonanno, 2004). We argue that the absorption of strain, accommodation of variability, and maintaining of stable equilibrium in organizations is located squarely in the relations among parts that become differentiated by creeping strain. By considering the gradual unfolding of creeping strain, we can focus more clearly on how the relations between focal and adjoining parts fragment or synchronize organizations.

Our concern with how well or poorly parts synchronize amidst creeping strain is rooted in the implications for organizational resilience. When people and systems cannot absorb the variability and quantity of events, and reach the limits of their adaptive capacities, organizations become vulnerable to rupture (Woods, 2006; Woods \& Wreathall, 2008). The over-accumulation of interruptions can shift an organization from resilient to fragile (Rudolph \& Repenning, 2002), exhausting its capacity to adapt as nonnovel disturbances cascade (Woods \& Branlat, 2011). Systems degrade and render organizations vulnerable to crisis (Rudolph \& Repenning, 2002). They become "brittle." In materials science, a material that has become brittle under high stress has lost its 
ability to stretch and adapt; it snaps, its original form ceasing to exist altogether (Gordon, 1978). In organizations, brittleness refers to the inability of members to make positive adjustments amidst strain (Sutcliffe \& Vogus, 2003); gaps in uniform functioning appear, as members cannot adjust strategies and recruit resources to handle mounting demand and strain (Woods \& Patterson, 2000; Woods \& Wreathall, 2008). Resilience has been compromised, to the point that the organization, fragmented into uncoordinated parts, is vulnerable to large-scale ruptures. The organization weakens through the accumulation and advance of challenges that are ignored or discounted (Williams, et. al., 2017).

Intergroup relations play a central role in understanding how relations between focal and adjoining parts shape organizational resilience amidst creeping strain. The underlying premise is that adversity in organizations pose challenges not simply for operational health but for relationships within those organizations (Kahn, Barton, \& Fellows, 2013; Pearson \& Clair, 1998; Powley, 2009). We build on that idea, placing intergroup relations in the foreground of what happens in organizations amidst creeping strain that slowly rather than immediately destabilizes organizations. Conceptualizing these processes requires grounding in theories from intergroup relations scholars.

\section{Intergroup Facets of Organizational Resilience}

We draw upon concepts from intergroup relations scholars to theorize dynamics among parts of organizations differentiated by strain. In particular, we are interested in how adjoining parts respond to focal parts in which strain is located. Organizations are social systems comprised of parts that may be nested (dyads within groups, teams within divisions), adjacent (business units, departments), and hierarchical (executives, front-line workers) in relation to one another. The collaborative and competitive dynamics between 
these parts mark organizations as "crucibles of intergroup relations" (Hogg, et.al., 2012: 233). The movements of adjoining parts to alleviate or avoid focal part strain signal whether intergroup competition or collaboration holds sway. More to the point, those reactions signal how adjoining parts frame focal part strain: as the legitimate province of the focal part, or as the province of the organization itself.

Examining this more closely requires theory about intergroup relations. Social identity theory (Tajfel \& Turner, 1985) created the intellectual foundation for intergroup relations, and as such, offers several key theoretical anchors. First, people are drawn toward social categories, such as organizational membership, religious affiliation, gender, and age cohort, as the means by which to classify themselves and others. These social categories allow people to more easily identify themselves relative to others (Tajfel \& Turner, 1985). Second, social identity theory predicts that those not part of a group with which people identify will be evaluated more harshly. Social identities thus depend on intergroup social comparisons by which people seek to confirm or establish their own distinctiveness in relation to members of defined out-groups (Turner, 1975). Individuals thus use their identifications with social groupings to define themselves, as with or against others (Hogg \& Terry, 2000). These dynamics enable us to conceptualize the reactions of adjoining to focal parts.

A further conceptual building block is that of intergroup boundaries. Building on social identity theory, Alderfer (1987) articulated the importance of physical and psychological boundaries to social identities in organizations. He noted that that the permeability of boundaries, i.e., the ease with which they can be crossed, regulates transactions among groups (Alderfer, 1987). Boundary permeability is shaped by the 
compatibility of interests between groups (Campbell, 1965; Sherif, 1966). When interests are compatible, boundaries between groups loosen, as members expand their ideas of who is inside the groups (i.e., who "we" are). The perception of incompatible interests leads to relatively impermeable boundaries, as groups close off from perceived “others" (Campbell, 1965; Sherif, 1966). Further, boundary permeability is shaped by group differences in power (Alderfer, 1987). More powerful groups, defined as those more able to obtain and deploy resources, can deny access to groups unable to demand or influence compliance (Tajfel \& Turner, 1979).

Social identity theory suggests that boundary permeability (and the power to regulate boundaries) is particularly integral to intergroup relations under conditions of resource scarcity (Tajfel \& Turner, 1979). As groups compete to claim scarce resources, negative relations are more likely, leading to greater boundary impermeability (Alderfer, 1987). Under these conditions, groups will compete with one another to acquire or protect resources, and become antagonistic (Campbell, 1965). Groups polarize, with positive feelings associated with own groups and negative feelings toward other groups (Turner, 1975), driving groups away from cooperative attitude and behavior (Sherif, 1966) amidst perceptions of zero-sum competition (Blake, Shepard, \& Mouton, 1964). Affective patterns are further buttressed by cognitive formations (and distortions) that anchor perceptions of "other" groups to positive or negative attributions, and justify intergroup cooperation or polarization, respectively (Alderfer, 1987; Turner, 1975).

Affective patterns and cognitive formations shape and are shaped by group member identifications. Social identity theory posits that the more that individuals identify with groups or organizations, the more likely they will think and act in 
accordance with that referent identity (Tajfel \& Turner, 1979). When identity threats or intergroup competition for resources (Kramer, 1991) make salient group identification, groups will more likely compete rather than cooperate (Brown \& Williams, 1984; Turner, 1975). When organizational identity is salient, adjoining parts will value organizational interests more (Ashforth \& Mael, 1989; Hogg \& Terry, 2000) and be more motivated to engage in prosocial behavior and cooperate with other groups (van Knippenberg, 2003). The salience of particular identities will thus anchor and justify how adjoining part members think about, feel towards, and act in relation to focal parts, according to whether those focal parts are considered inside or outside meaningful group boundaries.

Strengthening group identity can thus make adjoining part boundaries more rigid, building group capacity and making organizational resilience less likely. The shoring up of organizational identity can relax those boundaries (see Turner, 1975). This occurs as adjoining parts propagate particular causal attributions about focal parts. Causal attributions are lay explanations of cause-effect relationships (Matrinko, Douglas, \& Harvey, 2006; Ross, 1977). Adjoining parts can locate blame for differentiated strain within focal parts, unfolding situations, organizations, or other adjoining parts. Such attributions are then embedded within accounts that adjoining parts develop to justify actions toward focal parts. Accounts are discursive constructions of reality that describe or explain unfolding situations (Antaki, 1994; Maitlis, 2005), imbuing them with meaning that shapes subsequent group action (Weick, 1993). The power of adjoining parts within their organizations likely determines the nature and influence of their accounts, permeability of their boundaries, and actions toward focal parts. 
Our theorizing involves articulating pathways created by the movements of adjoining parts to provide or withhold resources - technology, knowledge, space, people, money - that could alleviate focal part strain. These pathways unfold in the context of creeping strain that gradually depletes the resources of focal parts. The pathways hinge upon if and when adjoining parts identify their interests as compatible with focal parts. We acknowledge the inevitable press in organizations for members to identify with their groups, via divisional and functional silos, incentive systems, and other aspects of loose coupling (Weick, 1976). This is, in effect, a press toward the fragmentation of parts. Yet cross-boundary collaboration and synchronization (Gittell \& Douglas, 2012; Rerup, 2009) remains possible amidst differentiated strain, along pathways described below.

\section{MODELING INTERGROUP PROCESSES OF ORGANIZATIONAL}

\section{RESILIENCE}

We draw on intergroup relations concepts to develop a process model that traces how the reactions of adjoining parts to a strained focal part shape processes of resilience. The process model (see Figure 1) offers a relatively simple version of focal-adjoining part dynamics, in which adjoining parts themselves remain unaffected by adversity. This enables us to theorize essential dynamics. Later, we examine some of the complications, including the strain of adjoining parts, affecting those dynamics.

Insert Figure 1 about here

As noted earlier, resilience is defined by the absorption of strain. While absorption of strain is typically theorized to occur at the collective level, we articulate three pathways that mark how and where that absorption occurs, and with what 
implications, when differential strain brings focal and adjoining parts to the foreground. The pathways - which we label integration, disavowal, and reclamation - all involve key intergroup relations, based on concepts discussed above. The pathways involve interrelated phases: the development of accounts by adjoining parts that guide their reactions to the focal part; the solidification or alteration of the identity that adjoining parts adopt which fuels those reactions; and the fragmented or synchronized shape of organizational resilience that results from adjoining part responses (see Table 1). The pathways reflect the logical possible reactions that groups have to the disturbances of other groups within their social system, as evidenced in studies by scholars focusing on group relations among nurses and physicians (Menzies Lyth, 1960), airline engineers and crews (Miller \& Rice, 1967), residential treatment center social workers and nurses (Miller \& Gwynne, 1973), and factory workers (Hirschhorn \& Gilmore, 1989). Those reactions are to turn away (isolate others), turn toward (support others), or remain still (status quo)(Miller, 1993). These movements drive the pathways described below.

Insert Table 1 about here

Each pathway is triggered by the emergence of differentiated strain that creates focal and adjoining parts in organizations. Gradually increasing demand on the focal part forces its members to stretch resources and capacities as best they can while maintaining operational competence. With accumulating demand, the focal part is increasingly unable to maintain a uniform response. Attempts to adjust strategies and create extra regions of adaptive capacity fail as the focal part becomes overmatched by accumulating quantities of demands and interruptions. The focal part is in danger of failing in its operational 
functioning; it requires assistance from adjoining parts that possess slack resources to prevent failure and reduce organizational vulnerability. At that point, adjoining part reactions can traverse distinct pathways. Of the three pathways, integration represents the most synchronicity amongst parts, disavowal the most fragmentation, and reclamation somewhere between the two. Integration and reclamation involve moving toward a focal part, immediately or later; disavowal involves remaining still or turning away. We use the hospital ED to illustrate these pathways. The ED is the focal part; adjoining parts include radiology, labs, inpatient floors, consulting services, and senior hospital leaders.

\section{Integration}

The integration pathway involves maintaining synchronicity among adjoining and focal parts, which join and remain together to create a larger whole to enable resilience.

Adjoining part accounts. Adjoining parts remain connected to and aware of mounting strain within the focal part by developing accounts that link their functioning. Adjoining parts perceive their interests as compatible with the focal part, which they move to include as an in-group. In the hospital, for example, radiology and lab areas add extra technicians to speed diagnostic testing; the admitting floor shifts personnel to speed up the admittance of more patients; and the Chief Medical Officer attempts to divert ambulances to other EDs. We theorize that these movements reflect adjoining parts embracing accounts that ascribe focal part strain to the situation, the organization, or other adjoining parts. The head of radiology tells her staff that the ED is becoming increasingly overwhelmed by psychiatric hospital closures and needs their help. Lab and radiology department leaders tell their staff that an overwhelmed ED, as the hospital's key entry point, will affect other areas as well. In attending to weak cues that allow 
attentional coherence across group boundaries (Rerup, 2009), they engage in boundary work to connect ancillary and ED areas and facilitate patient flow (Hilligoss, 2014).

Adjoining part identifications. The accounts of adjoining parts in this pathway are founded on their identifying as part of the larger organization. This identification enables adjoining parts to remain connected to focal parts and to function as integrated units, even when demand ebbs and strain is relieved. Adjoining and focal parts work together to "size up" and create joint understandings of developing scenarios and problems (Bigley \& Roberts, 2001). Unlike problem-solving networks that arise and, once crises pass, dissolve in high-reliability organizations (Roberts, Stout, \& Halpern, 1994), these connections remain necessary for organizations to stay resilient amidst constant pulls toward fragmentation. Adjoining parts emphasize the compatibility of interests, enabling their members to maintain in-group empathy (Sherif, 1966). In this respect, accounts and identifications are recursive: accounts frame and shape how adjoining parts identify (with) the focal part, which in turn guides further accounts. Such mutual influencing occurs for each of the three pathways (as depicted in Figure 1).

In the hospital, the Chief Medical Officer and the lab, radiology, and psychiatry departments act as if their work is connected to that of the ED. The Chief Medical Officer talks about the ED as the "front lines," encouraging other departments to see how events in the ED affect the functioning and vulnerability of the hospital itself. The other parts coordinate their responses to strains that emerge within the ED. We argue that in this pathway, adjoining part members base their responses not simply on organizational identities but on relational identities, i.e., their self-definitions include their collaborative relationships with the focal part (Hogg, et. al., 2012). Thus, admitting floor nurses define 
their unit partly on the basis of facilitating ED patient flow. Adjoining and focal parts do not simply create a superordinate entity but act as if their interests are inextricably linked.

Shape of organizational resilience. When organizational resilience is described as "bouncing back" from adversity, the idea is that the organization regains "shape" after being deformed by strain (Sutcliffe \& Vogus, 2003). In integration, the organization's shape remains a reasonably coherent system of linked parts across which flow necessary resources. The organization retains uniform functioning throughout, covering gaps that would otherwise leave the organization brittle (Woods \& Patterson, 2000), as when the ED, with the help of adjoining parts, ensures consistently appropriate and timely patient care. Adjoining and focal parts are synchronized; together, they adapt to potentially disabling quantities of interruptions and strain. The creation of a shared concern for and focus on the organization (Ashforth \& Mael, 1989); the attending to weak cues from front lines (Rerup, 2009); and the sizing up of developing situations (Bigley \& Roberts, 2001) enable organizations to be less vulnerable to crises that could arise through lack of coordinated attention to strained capacities (see Rerup, 2009: Woods \& Wreathall, 2008).

\section{Disavowal}

In the disavowal pathway, differentiated strain fragments organizations into disconnected parts. Adjoining parts remain separate from the focal part, which is left to its own struggles. Adjoining parts, in effect, repudiate connections to the focal part, as if denying shared contexts and goals.

Adjoining part accounts. Adjoining parts remain distant from the focal part, whose interests they perceive as incompatible; they act as if moving toward the focal part will diminish scarce resources or otherwise prove compromising. Adjoining parts adopt 
a threat-rigidity response: they react to threat-based stress and anxiety by restricting information, constricting control, and conserving resources (Staw, Sandlelands, \& Dutton, 1981). They blame the focal part (or other adjoining parts) for its outstripped capacity, strain, and operational difficulties. Their accounts emphasize the need to guard in-group boundaries and resources. In the hospital, the admitting floor, lab and radiology departments, and psychiatry consult services rebuff requests for quicker responses to ED needs. Their justifying accounts consider the ED inefficient or incompetent, or blame hapless hospital administrators for lack of foresight. Such contextualized accounts are easily developed: hospitals include distinct professional perspectives (Apker, Mallak, \& Gibson, 2007), strong hierarchies (Axelrod \& Cohen, 1999), and practices that encourage physicians to work against rather than with one another (Hilligoss, 2014).

Disavowal processes may be partly shaped by the distress of the focal part. The distress of one group can trigger defensive reactions from other groups, whose members act as if distress were contagious (Miller, 1993; Obholzer, 1994). Distress thus has the potential to enhance perceptions of the focal part as an out-group - perceptions which fuel enduring accounts that justify adjoining parts disavowing the focal part. We also suggest that focal parts can develop their own causal attributions and accounts by which they blame adjoining parts and create narratives of their victimization (see Obholzer, 1994). ED members might castigate others in the hospital as incompetent, self-oriented, and indifferent, and hospital leaders as unable to intercede. Such complementary accounts maintain boundary impermeability between adjoining and focal parts, rendering them unable to join together to size up developing situations, create attentional coherence, and synchronize efforts (see Bigley \& Roberts, 2001; Rerup, 2009). 
Adjoining part identifications. Even as demand slows and strain ebbs, adjoining parts can disavow the focal part, continuing to propagate accounts based on restrictive ingroup identifications. Admitting floors, lab and radiology departments, and psychiatry consults continue to pay little attention to the struggles within the ED, whose members strive to recover from a degraded state of performance. The Chief Medical Officer does little to dispel this insularity, colluding with the adjoining departments continued perception of the ED as a separate entity. Adjoining parts may continue to reinforce the idea of incompatible interests that maintain in-group ethnocentrism and out-group antagonism (Sherif, 1966). These dynamics can be reinforced by cognitive biases, such as confirmation biases and availability heuristics (Tversky \& Kahneman, 1981), by which adjoining parts filter information in ways that maintain threat-rigidity responses. Such responses, in effect, leave the focal part "quarantined" within the organization. The focal part remains isolated within boundaries it lacks the power to control or influence.

Shape of organizational resilience. Resilience is weakened when parts of a system are pathologized, ignored, distanced, withheld from, or treated with indifference (Shalev \& Errera, 2008). In the disavowal pathway, such actions affect the shape of the organization: parts are fragmented, in effect creating multiple organizations with which members differentially identify. This fragmentation sharply impedes or blocks the flow of resources to the focal part. The focal part can become a "casualty" of disavowal, sharply diminished by the lack of help. The ED loses members, its staff burned out not simply by the pace and intensity of the work but by the dispiriting sense of failing in their roles (Wears \& Perry, 2006). The organization becomes vulnerable to crises that arise through lack of attentional coherence (Rerup, 2009); adjoining parts "normalize" signals about 
dangerously strained capacities (Weick \& Sutcliffe, 2006) rather than collectively attend to what they imply about crises that may be incubating (Turner, 1976; Williams, et. al., 2017). ED members, compromised by demand that gradually outstrips their capacities, are at risk of misdiagnosing patients, committing medication errors, and badly prioritizing efforts. There is simply greater risk that, as the fragmented organization becomes brittle, real crises will ensue for which members are unprepared (Roux-Dufort, 2009; Woods \& Wreathall, 2008).

\section{Reclamation}

The reclamation pathway involves adjoining parts initially distancing from and then moving to include and help the focal part. Initially, adjoining parts follow the disavowal pathway, using blaming attributions and accounts to justify withholding resources from the focal part. At some point, however, they join with the focal part, supporting its efforts to regain effective functioning. As noted further below, some condition shifts — in the organization, between adjoining and focal parts, within leadersthat enables adjoining parts to move to help focal parts. The nature and timing of reclamation determines the extent to which focal and adjoining parts remain, on balance, synchronized or fragmented, and ultimately, determines the resilience of the organization.

Adjoining part identifications. Reclamation occurs when adjoining parts revise accounts that had initially blamed a focal part for inviting overwhelming strain ("you"), and shift blame to the situation/organization ("us") or to other adjoining parts ("them"). In effect, the focal part shifts from an out-group to an in-group. Lab and radiology department leaders, after rebuffing ED demands for extra help, shift to blame hospital administrators for not staffing to meet demand. Such revised accounts enable adjoining 
parts to either annex focal parts (incorporating them into expanded identities) or shift from group to organizational identifications by joining with focal parts to size up and develop strategies to handle accumulating strain (Bigley \& Roberts, 2001). The lab and radiology departments (as a superordinate "part") now see the ED as a compatriot, struggling to work effectively amidst inadequate resources just as they do. Adjoining parts thus shift to positive intergroup relations and direct resources toward the focal part.

Shape of organizational resilience. Reclamation can leave adjoining and focal parts more or less cohered into a system of linked parts. We theorize that such coherence varies according to the presence of lingering fissures between adjoining and focal parts. More precisely, we suggest that the timing of reclamation process can minimize, create, or deepen such fissures. Consider how the "quarantine" of the focal part effectively constricts strain within its borders. This can insure the integrity of the organization; medical quarantines separate infected people from others, constricting disease to minimize the possibility of harming wider communities (McKenzie, Pinger, \& Kotecki, 2011). The temporary disavowal of the focal part thus becomes integral to the survival of the larger whole, buying time to stabilize the larger system (Wildavsky, 1991). Once the organization has prepared itself (or strain has subsided), the quarantine can be lifted and the focal part reclaimed. The organization, its shape now a coherent whole, is less vulnerable to crises due to lack of coordinated attention to warning signals.

There are, however, quarantine-related tipping points (McKenzie, et. al., 2011). If the focal part is disavowed for too long, that part can become so degraded as to be no longer viable for reclamation. In medical terms, the quarantine has isolated individuals for so long that they are too compromised to thrive. In our terms, organizational 
resilience is compromised when members are stuck too long in stagnation and inertia (Kantur \& Isein-Say, 2012). We argue that, to the extent that reclamation occurs quickly and fully, the degradation of the focal part will recede, enabling its members to coordinate effectively with adjoining parts to avert potential crises. If the other areas of the hospital, for example, work quickly to provide resources to clear the backlog of waiting patients, the hospital will retain its coherent shape. If reclamation occurs slowly or superficially, fissures between focal and adjoining parts will exist, leaving the organization vulnerable. The ED, too long bereft of help, will remain partly adrift, unable to coordinate flows of knowledge and information with other parts of the hospital to prevent crises. The organization becomes brittle, its shape fragmented. Adjoining and focal part are unable to work uniformly to cover dangerous gaps in functioning.

\section{Influences on Pathways Taken}

Adjoining parts move along the pathways according to how they navigate several key junctures, at which decisions regarding how to engage the focal part are required. The first juncture occurs after accumulating demand outstrips capacity, straining the focal part. At that point, adjoining parts either start along integration or disavowal pathways. The second juncture occurs after adjoining parts have disavowed the focal part; as strain continues to mount, adjoining parts either continue to disavow or shift to reclaim the focal part. (In point of fact, there are multiple places at which this second type of juncture can occur; i.e., at various points throughout a creeping strain, adjoining parts can face choices about continuing to disavow or to shift to reclaim the focal part). We examine key influences on what occurs at these two types of junctures, working from key concepts from social identity theory (Tajfel \& Turner, 1985), corollary intergroup 
relations concepts (Alderfer, 1987; Ashforth \& Mael, 1989; Hogg, et. al., 2012), and organizational resilience frameworks (Kantur \& Isein-Say, 2012; Sutcliffe \& Vogus, 2003; Wildavsky, 1991).

There are several types of influences on the pathways. Two influencesadjoining part resources, and the strain upon adjoining parts - determine whether adjoining parts have the capacity to support the focal part. These are critical determinants at both junctures, in that they dictate whether adjoining parts are initially available for integration processes, and later, whether they have become available for reclamation processes. Three other influences - the interdependence of adjoining and focal parts, the history of their relations, and their relative power-point to the existing intergroup relationships that facilitate or undermine adjoining part willingness to provide resources to the focal part. Without capacity, of course, adjoining parts willing to help the focal part will be unable to do so fully. These influences are described below.

Adjoining part capacity. We have assumed thus far that adjoining parts have the capacity to relieve focal part strain. Yet adjoining parts may lack the resources necessary to do so (i.e., people, technology, space, ideas, finances, empathy). Adjoining parts will vary in terms of such resources and thus how available they are to help the focal part. As social identity theory suggests, group identities become salient when resources are scarce (Kramer, 1991), causing groups to protect their resources (Campbell, 1965). When there are slack resources, organizations have resource cushions that allow them to adapt successfully to internal pressures for adjustment (Bourgeois, 1981). Slack resources can be available, not yet assimilated into organizational design; $\underline{\text { recoverable, }}$, shifted from 
places in organizations in which they are currently deployed; or potential, generated by organizational members to fill current gaps (Bourgeois \& Singh, 1983; Feldman, 2004). Scholars suggest that when organizations have available or easily recoverable slack resources, resilience is an easier proposition (Woods, 2006; Woods \& Wreathall, 2008). Slack resources enable adjoining parts to afford to make boundaries permeable to the focal part. In a hospital with a relative abundance of lab workers, space, and machines, overwhelmed ED physicians can order anticipatory batteries of tests rather than wait to order more precise tests (Hilligoss, 2014), which shifts the overload to another part of the hospital (Wears \& Perry, 2006). Slack resources thus make it more likely that adjoining parts will initially develop accounts consistent with integration rather than disavowal. The transformation of potential to available resources (Bourgeois \& Singh, 1983; Feldman, 2004) can also enable adjoining parts to relax assumptions of scarcity, and move to reclaim the focal part. In the hospital, adding three consulting psychiatrists moonlighting from another hospital provides needed support to the ED; the consulting service, by providing those resources, moves to reclaim the ED.

Further, adjoining parts might not be available to integrate or reclaim focal parts when they are focal parts, i.e., when adjoining parts are strained by adversity. Adversityrelated strain can affect multiple parts of an organization simultaneously, or creep into contiguous parts, creating event chains (Morgeson, Mitchell, \& Liu, 2015); or multiple, distinct strains can affect multiple parts, triggered by different sources of adversity, and create event clusters (Morgeson, et. al., 2015). Either way, adjoining parts can lose the potential for synchronization. As their own operations degrade, they are unable to build 
attentional coherence across boundaries (Rerup, 2009) or join with others to build collective, coherent understandings of activity systems (Bigley \& Roberts, 2001).

This scenario adds more complexity to the relatively straightforward pathways we describe above. Parts of organizations can shift from adjoining to focal, or vice versa. In the hospital, for example, failing technology might significantly disrupt the radiology department, whose members had started to but could not continue to relieve ED strain. Or the psychiatric service's capacity to provide consults becomes gradually overwhelmed by the quantity and severity of ED mental health patients, to the point that its physicians cannot respond effectively to ED requests. In such situations, the ability of adjoining parts (now also focal parts) to provide necessary resources is compromised. They are far less available to integrate or reclaim the (other) focal part. Adjoining parts are then likely to develop accounts that position the focal part as an out-group, and make their boundaries less permeable in relation to that part (Alderfer, 1987).

Facilitating and undermining willingness to help. Three factors influence the willingness of adjoining parts to provide resources to the focal part. First, the permeability of adjoining part boundaries is likely influenced by interdependence, i.e., how tightly coupled adjoining and focal parts are in their daily operations. Interdependence between members depends on how tasks are executed, skills and resources are distributed, performances are assessed, and outcomes are rewarded (Wageman, 1995). Each of these dimensions can tightly or loosely couple different parts of organizations. This offers a mixed blessing. Tightly coupled parts might lead to the spread of strain: creeping strain in one part can occur in another whose tasks are interdependent. Yet tight coupling can also lead specific parts to regularly identify (with) 
other parts as part of the same organization, and increase the possibility of parts to be aware of what is occurring within other parts. So too can work practices such as crossfunctional teamwork, strategic and tactical team meetings, and boundary spanners that routinely integrate parts of organizations (Bigley \& Roberts, 2001; Gittell, 2008). Such integration creates a sense of compatible interests between adjoining and focal parts, facilitating possible integration or reclamation.

We suggest that as gradually mounting strain creates focal and adjoining parts, their pre-existing interdependence likely shapes what occurs. When a cross-disciplinary team of leaders who are measured and incentivized in terms of a hospital's overall performance makes decisions about human, financial, and technological resources, the diagnostic services (lab, radiology, consultants) and admitting floors will likely integrate rather than disavow the ED. Or, as the ED is strained, the Chief Medical Officer can decide to split the laboratory department, dedicating a portion of its staff, technology, and time to the ED — and thus shift lab members' allegiances, tying metrics and incentives to ED performance. Such actions restructure the organization to enable reclamation of focal parts (see Wildavsky, 1991).

Second, the intergroup history between adjoining and focal parts likely facilitates or undermines the former's willingness to help the latter. There are likely previous instances of adjoining parts integrating, disavowing, and reclaiming focal parts.

Presumably, these instances left members of various parts feeling more connected to or disconnected from one another, which has implications for how willing they are to alleviate strain going forward. We thus offer a temporal perspective (Morgeson, et. al., 2015) to the dynamics of availability and boundary permeability between parts. We 
theorize that when relations between specific parts have a legacy of being largely positive, adjoining parts are more likely to be available to integrate or reclaim specific focal parts. In the hospital, a history of the laboratory and radiology departments coordinating well with one another and with the ED to offset patient influxes makes later integration and reclamation more likely. Conversely, repeated disavowals of the ED by the psychiatric consulting service make future disavowals more likely. Such patterns are likely to be reinforced by enduring accounts that become, in effect, attached to focal parts themselves rather than to adverse situations (see Alderfer, 1987; Maitlis, 2005).

Third, the power of adjoining parts relative to the focal part likely influences pathway choices. As noted earlier, differences in power between groups shape boundary permeability (Alderfer, 1987): more powerful groups have the ability to obtain, deploy and withhold resources in relation to less powerful groups (Tajfel \& Turner, 1979). This suggests that when adjoining parts are more powerful than the focal part, they have the authority to decide whether to integrate, disavow, and reclaim. The radiology department, as a revenue generator in the hospital may be more powerful than the ED and within limits can set its own rules for engaging the ED. Alternatively, if the focal part has more power (directly, or indirectly via access to powerful senior leaders), it can compel adjoining parts to provide resources necessary for relieving strain, initially or later. The ED might have more influence in the hospital than the newly instituted psychiatric consulting service, for example, and can, within limits, insist on that service's cooperation. Either way, intergroup power differences are likely to be buttressed and justified by rationalizing adjoining part accounts and in-group/out-group identifications.

\section{Leaders as Agents}


Throughout the descriptions of the three pathways, leaders of adjoining parts and of organizations were influential agents on if and when adjoining parts move to integrate or reclaim the focal part. In the hospital example, the Chief Medical Officer, and the leaders of the radiology, lab, inpatient floors, and consulting services were all instrumental in providing or withholding resources necessary to relieve ED strain. Leaders have the clearest potential in organizations to reinforce intergroup relational identity, in which groups define themselves partly in terms of relationships with other groups (Hogg, et. al., 2012). Intergroup leadership is crucial given the pulls toward fragmentation among parts of organization—-between union and management, headquarters and satellite offices, senior leaders and front-line workers - that become embedded in structures, routines, and processes (Gordon, 1978; Hilligoss, 2014). Leaders are influential agents, able to use their authority to bridge or exploit gaps between parts of organizations. How adjoining and senior executive leaders use that authority determines which pathways are followed as focal part strain accumulates, and the nature of the justifying accounts and identifications they develop to shape those choices.

Leaders can influence intergroup pathways in distinct ways. In the structuralist view of leadership (see Podolny, Khurana, \& Hill-Popper, 2005), they can create or alter the interdependence of adjoining and focal parts, the better to link their fortunes and instill intergroup relational identities. This can include reward systems and corresponding metrics that tightly couple adjoining and focal part outcomes; structuring reporting relationships such that leaders think of and treat parts as connected; and job descriptions that require members to work across boundaries (Bigley \& Roberts, 2001; Gittell, 2008; Wageman, 1995). Adjoining part leaders can also advocate with senior 
executives, or join with peers, to recover or generate slack resources (Bourgeois \& Singh, 1983) that could relieve their own strain and render them available to help the focal part. In the social construction view of leadership, leaders are key agents in shaping how their followers think of and act toward others. Leaders are makers of meaning; they author narratives that frame events, situations, and actions in ways that give sense to others (Weick \& Sutcliffe, 2001; 2006). In practice, this can involve leaders instilling intergroup relational identities through the use of rhetoric that emphasizes both the distinct contributions of parts and the integrity of the organization-as-a-whole (Hogg, et. al., 2012). Adjoining part members thus perceive their interests as aligned with a focal part, whose effectiveness becomes integral to adjoining parts' health and welfare, and ultimately, that of the organization itself. Such rhetoric is embedded in the accounts that leaders develop and propagate to justify decisions and actions related to integration, disavowal, and reclamation of the focal part.

In addition to their use of rhetoric, adjoining part and senior executives can encourage mindfulness of operations to enable resilience (Sutcliffe \& Weick, 2013; Weick \& Sutcliffe, 2006). Mindfulness is inculcated when leaders bring attention to how adjoining part members may be simplifying complex realities, ignoring focal part strain as information about the vulnerability of the organization-as-a-whole. Leaders can respond to weak signals about mounting strain by posing questions to adjoining parts that shift them from complacency and narrowed focus and toward considering the larger picture of how organizations become vulnerable (Roberts \& Rousseau, 1989; Weick \& Sutcliffe, 2001). Leaders can become rightfully suspicious of accounts that solely blame the focal part; and they can act upon those suspicions by involving adjoining parts in 
developing and acting on the basis of more complex accounts (see Weick \& Sutcliffe, 2006). The mutually reinforcing interplay of structuralist and social constructivist dimensions of leadership are crucial here: more complex accounts and shared identifications can shape and be shaped by structural dimensions of organizational life that press adjoining and focal part members to join together.

\section{CONTRIBUTIONS AND FUTURE DIRECTIONS}

Organizational resilience can be understood partly in terms of dynamics that take place among parts of organizations differentiated by creeping strain. In this section we offer three contributions to organizational resilience theory, research, and practice. First, we articulate the geography of strain, in which unfolding localized adversity can fragment organizations into distinct parts. Second, we leverage intergroup relations concepts to theorize how dynamics between those parts enact pathways - integration, disavowal, and reclamation — that lead to fragmented or synchronized organizations, shaping their resilience. Third, we focus on temporal aspects of organizational resilience that shape relations among parts affected by creeping strain.

\section{Geography of Strain}

We have argued that when strain emerges in bounded parts of organizationsgroups, departments, functions, and hierarchical levels - it becomes differentiated rather than uniform across the organization. This argument challenges the implicit premise of organizational resilience scholarship that the whole organization is the primary actor amidst adversity. This premise holds that an "organizational intelligence" (Catino \& Patriotta, 2013) guides the collection and processing of information and the diversion of resources to enable the organization to adapt and perform (Sutcliffe \& Vogus, 2003; 
Woods, 2006). Differentiated strain fragments organizations and makes this process complex. We thus reimagine organizational resilience, whose guiding metaphor has been elasticity, i.e., the ability to absorb strain without permanently losing shape. We suggest instead that differentiated strain redefines the shapes of organizations, breaking larger systems into parts that vary in openness to and support of one another. It is not simply that the resilience of individuals and units, and of their organizations, is redundant or additive, as scholars imply (Vogus \& Sutcliffe, 2007), but that relations across emergent borders can determine collective resilience.

The geography of strain is not haphazard. Differentiated strain is often located in the front lines of organizations. It is at the front lines - the ED to which ambulances deliver patients, a TSA shift confronted by masses of travelers, a social worker unit gradually overwhelmed by families broken by opioid addictions - that mounting strain appears. Adversity can, of course, emanate from other parts of organizations, such as when leaders make strategic errors or errant investments. Weick (1988) offers a telling example of the Bhopal crisis, in which senior leaders allocated limited resources and set in motion deteriorating conditions that left a seemingly unimportant facility dangerous. Even in such cases, strain tends to emerge at the front lines. Their efforts to alert others to those developments are often ignored. Senior leaders can avoid their responsibility for sizing up developing situations (Barton, Sutcliffe, Vogus, \& DeWitt, 2015) by remaining impervious to critical information from those they consider to have lesser knowledge or relevance (Silbey, 2009) — even as they later blame lower levels (Perrow, 2007). Such stratifications of hierarchy and power make synchronization difficult. 
There are several implications here for organizational resilience scholarship.

First, scholars need to consider the impact of multiple adjoining parts responding differently to the same focal part. Our argument simplified this issue, treating adjoining parts as singular in their response. Yet responses to differentiated strain may involve political dynamics, with adjoining parts responding not only to a focal part but also to one another. Second, we need to understand more completely what occurs when adjoining parts are strained to the point that they become focal parts. Multiple, adjacent focal parts can spark troublesome dynamics, such as debilitating competition over scarce resources. Third, scholars can consider how strain is differentiated across race, gender, socioeconomic, religious, and occupational groups in organizations. While our work focused on operational units, the larger point is that differentiated strain fragments organizations. This logic can apply as well to other types of organizational parts, such as demographic segments, with similar implications for resilience (see Chan \& Anteby, 2016; DiBenigno \& Kellogg, 2014; Leana, Mittell, \& Stiehl, 2011).

\section{Intergroup Relations of Resilience}

Our premise is that organizational resilience is largely a social process. The social dynamics that we theorize occur between bounded parts of organizations. The three pathways described above integrate the core principles of social identity theory (Tajfel \& Turner, 1979) and its elaborations (Alderfer, 1987; Ashforth \& Mael, 1989; Hogg \& Terry, 2000). We seek to expand organizational resilience theory beyond existing frameworks developed in the context of organizational crisis and recovery (see Williams, et. al., 2017). The intergroup relations involve adjoining parts moving along particular pathways according to if and when they open or close their boundaries to a focal part. 
These movements are based on whether they identify with their own groups, or with the organization itself. As these identities hold or shift, adjoining and focal parts engage in positive or negative interactions, buttressed by accounts that justify those interactions. These social processes shape how effectively those parts synchronize or remain fragmented; ultimately, they shape the strength and weakness of the organization and its vulnerability to crisis (see Roux-Dufort, 2017; Turner, 1976).

These processes raise several questions for theory and research. First, we largely focused on relations between adjoining and focal parts; we minimized potential differences within adjoining parts. It is likely, however, that adjoining part members will differ in their impulses to remain apart from or alleviate focal part strain, as a function of different biases or motivations (e.g., prosocial, competitive). Such splits might well result in ambivalent relations with a focal part; adjoining parts can start and stop and backtrack, tangling the straightforward pathways we theorize. Second, members of adjoining parts will have reactions, such as territoriality or compassion, that render them more or less willing to provide a focal part with needed resources. Empirical work is necessary to place those reactions within larger contexts - of hierarchy, power, and politics - that shape intergroup relations. Third, leaders' attempts to instill intergroup relational identities are likely shaped by their own styles, skills, and behaviors; this remains to be theorized or examined in organizations fragmented by differentiated strain.

\section{Organizational Resilience in Time}

Relations among parts differentiated by strain surface temporal dimensions of organizational resilience. These dimensions are not routinely theorized in organizational resilience scholarship (for exceptions, see Williams, et. al., 2017; Woods \& Branlat, 
2011; Woods \& Wreathall, 2008). The traditional focus on sudden events emphasizes large-scale surprises that affect wide segments of organizations all at once rather than separately (Comfort, 2007). Such events force synchronicity among organizational parts, relatively quickly, blurring distinctions between focal and adjoining parts; or rather, the organization itself becomes focal. The magnitude and speed of adversity thus moderates what type of resilience frame is necessary. Adversity that advances slowly, located in some bounded parts and not others, requires a focus on how relations among those parts play out over time. In this frame, we suggest, resilience is a matter of greater and faster synchronicity. Resilience is enabled when parts of organizations join together to ensure that localized strain does not deepen and spread, which would diminish coordination and leave organizations vulnerable to larger-scale adversity.

Several temporal aspects are important to examine further. First, the speed with which focal part strain accumulates may affect how much time there is for adjoining parts to shift from disavowal to reclamation. It is not clear how much time adjoining parts might need to gather intelligence from front lines, convene members to size up activities, and coordinate collective attention (Bigley \& Roberts, 2001; Rerup, 2009). Second, our argument focused on single creeping developments in which strain accumulates in a relatively straightforward fashion. We did not theorize such accumulation amidst event clusters (i.e., multiple events that occur closely in time and space) or event chains (i.e., events that cause further events downstream or over time)(Morgeson, et. al., 2015). Empirical research can help map how accumulation of strain within event clusters and chains is exponential rather than additive, with implications for the time necessary for parts to join together to alleviate strain and ensure resilience. 
Scholars can also examine more closely how the history of certain focal and adjoining parts shape pathway choices. That history might involve previous attempts to provide resources amidst adversity; in particular, how those attempts were experienced, their outcomes, and the relationships that they facilitated or undermined, all of which can carry over into later accounts and behaviors. Intergroup history is also likely to both shape and be shaped by other influences, such as structural interdependence or the power of adjoining parts. Another temporal dimension involves the timing of when adjoining parts reached out to reclaim the focal part. Empirical work can help identify the implications of how long a focal part was left isolated ("quarantined") before adjoining parts alleviated its strain. This work can specify how the timing of reclamation matters for synchronization or fragmentation, and ultimately, for organizational resilience.

\section{CONCLUSION}

In this article we look closely at how differential strain fragments organizations into parts. What remains are relationships between those parts that involve integration, disavowal, and reclamation. How those relationships play out ultimately impacts organizational resilience. Reason (1990) notes how underlying organizational problems result from "latent pathogens" that compromise defenses against challenging events; and that aligned workforces are best able to remove those pathogens. We raise the question of what occurs when the relations between parts differentiated by strain are themselves latent pathogens, fragmenting workforces. Our response to this question offers a compelling direction for future scholarship on how organizations become resilient or made brittle amidst adversity that unfolds over space and time. 


\section{REFERENCES}

Alderfer, C. P. (1987). An intergroup perspective on group dynamics. In J. Lorsch (Ed.), Handbook of organizational behavior, pp. 190-222. Englewood Cliffs, NJ: Prentice-Hall.

Antaki, C. (1994). Explaining and arguing: The social organization of accounts. NY: Sage.

Ashforth, B. E., \& Mael, F. (1989). Social Identity Theory and the organization. Academy of Management Review, 14(1), 20-39.

Apker, J., Mallak, L. A. \& Gibson, S. C. (2007). Communicating in the "gray zone:" Perceptions about emergency room physician hospitalist handoffs and patient safety. Academic Emergency Medicine, 14(10), 884-894.

Axelrod, R. \& Cohen, M. D. (1999). Harnessing complexity. New York: The Free Press.

Barton, M. A., Sutcliffe, K. M., Vogus, T. J., \& DeWitt, T. (2015). Performing under uncertainty: Contextualized engagement in wildland firefighting. Journal of Contingencies and Crisis Management, 23(2), 74-83.

Bigley, G. A., \& Roberts, K. H. (2001). The incident command system: High-reliability organizing for complex and volatile task environments. Academy of Management Journal, 44(6), 1281-1299.

Blake, R. R., Shepard, H. A., \& Mouton, J. S. (1964). Managing intergroup conflict in industry. Houston: Gulf Publishing. 
Boin, A., \& McConnell, A. (2007). Preparing for critical infrastructure breakdowns: the limits of crisis management and the need for resilience. Journal of Contingencies and Crisis Management, 15(1), 50-59.

Boin, A., \& Van Eeten, M. J. (2013). The resilient organization. Public Management Review, 15(3), 429-445.

Bonanno, G. A. (2004). Loss, trauma, and human resilience: have we underestimated the human capacity to thrive after extremely aversive events? American Psychologist, 59(1), 20.

Bourgeois, L. J. (1981). On the measurement of organizational slack. Academy of Management Review, 6(1), 29-39.

Bourgeois, L. J. \& Singh, J. V. (1983). Organizational slack and political behavior among top management teams. Academy of Management Proceedings (1), 43-47.

Brown, R., \& Williams, J. (1984). Group identification: The same thing to all people? Human Relations, 37(7), 547-564.

Campbell, D. T. (1965). Ethnocentric and other altruistic motives. In D. Levine (Ed.), Nebraska Symposium on Motivation, 283-311. Lincoln: Univ. Nebraska Press.

Catino, M., \& Patriotta, G. (2013). Learning from errors: Cognition, emotions and safety culture in the Italian air force. Organization Studies, 34(4), 437-467.

Chan, C. \& Anteby, M. (2016). Task segregation as a mechanism for within-job inequality: Women and men of the Transportation Security Administration.

Administrative Science Quarterly, 61(2), 184-216. 
Christianson, M. K., Farkas, M. T., Sutcliffe, K. M., \& Weick, K. E. (2009). Learning through rare events: Significant interruptions at the Baltimore \& Ohio Railroad Museum. Organization Science, 20(5), 846-860.

Comfort, L. K. (2007). Crisis management in hindsight: Cognition, communication, coordination, and control. Public Administration Review, 67, 189-197.

Cunha, M. P., Clegg, S. R., \& Kamoche, K. (2006). Surprises in management and organization: Concept, sources and a typology. British Journal of Management, 17(4), 317-329.

DiBenigno, J., \& Kellogg, K. C. (2014). Beyond occupational differences the importance of cross-cutting demographics and dyadic toolkits for collaboration in a US hospital. Administrative Science Quarterly, 59(3), 375-408.

Dutton, J. E., Worline, M. C., Frost, P. J. \& Lilius, J. (2006) Explaining compassion organizing. Administrative Science Quarterly, 51(1): 59-96.

Feldman, M. S. (2004). Resources in emerging structures and processes of change. Organization Science, 15(3), 295-309.

Gittell, J. H. (2008). Relationships and resilience care provider responses to pressures from managed care. Journal of Applied Behavioral Science, 44(1), 25-47.

Gittell, J. H., \& Douglass, A. (2012). Relational bureaucracy: Structuring reciprocal relationships into roles. Academy of Management Review, 37(4), 709-733.

Gordon, J. (1978). Structures. Harmondsworth, UK: Penguin Books.

Hilligoss, B. (2014). Selling patients and other metaphors: A discourse analysis of the interpretive frames that shape emergency department admission handoffs. Social Science \& Medicine, 102, 119-128. 
Hirschhorn, L., \& Gilmore, T. N. (1989). The psychodynamics of a cultural change:

Learnings from a factory. Human Resource Management, 28(2), 211-233.

Hogg, M. A., \& Terry, D. I. (2000). Social identity and self-categorization processes in organizational contexts. Academy of Management Review, 25(1), 121-140.

Hogg, M. A., Van Knippenberg, D., \& Rast, D. E. (2012). Intergroup leadership in organizations: Leading across group and organizational boundaries. Academy of Management Review, 37(2), 232-255.

Hollnagel, E. \& Sundstrom, G. A. (2006). States of resilience. In E. Hollnagel, D. D. Woods \& N. Leveson (Eds.), Resilience engineering, 339-344. Aldershot, UK: Ashgate.

Hollnagel, E., \& Woods, D. D. (2006). Resilience engineering precepts. In E. Hollnagel, D. D. Woods \& N. Leveson (Eds.), Resilience engineering, 347-358. Aldershot, UK: Ashgate.

Hoot, N. R., \& Aronsky, D. (2008). Systematic review of emergency department crowding: causes, effects, and solutions. Annals of Emergency Medicine, 52(2), 126-136.

Horne, J. F., \& Orr, J. E. (1997). Assessing behaviors that create resilient organizations. Employment Relations Today, 24(4), 29-39.

James, E. H. \& Wooten, L. P. (2010). Leading under pressure. New York: Taylor \& Francis.

Kahn, W. A., Barton, M. A., \& Fellows, S. (2013). Organizational crises and the disturbance of relational systems. Academy of Management Review, 38(3), 377 396. 
Kantur, D., \& İşeri-Say, A. (2012). Organizational resilience: A conceptual integrative framework. Journal of Management and Organization, 18(6), 762-773.

Kinman, G. (2009). Emotional labour and strain in "front-line" service employees: Does mode of delivery matter? Journal of Managerial Psychology, 24(2), 118-135.

Kramer, R. M. (1991). Intergroup relations and organizational dilemmas: The role of categorization processes. Research in Organizational Behavior, 13, 191-228.

Leana, C. R., Mittal, V., \& Stiehl, E. (2012). Organizational behavior and the working poor. Organization Science, 23(3), 888-906.

Madni, A. M., \& Jackson, S. (2009). Towards a conceptual framework for resilience engineering. Systems Journal IEEE, 3(2), 181-191.

Maitlis, S. (2005). The social processes of organizational sensemaking. Academy of Management Journal, 48(1), 21-49.

Martinko, M. J., Douglas, S. C., \& Harvey, P. (2006). Attribution theory in industrial and organizational psychology: A review. In G. P. Hodgekinson \& J. K. Ford (Eds.), International Review of Industrial and Organizational Psychology, 127-187. New York: John Wiley.

McFarlane, A. C. \& Norris, F. H. (2006). Definitions and concepts in disaster research. In F. H. Norris, S. Galea, J. Friedman \& P. J. Watson (Eds.), Methods for disaster mental health research, 3-19. New York: Guilford Press.

McKenzie, J., Pinger, R., \& Kotecki, J. E. (2011). An introduction to community health. New York: Jones \& Bartlett Publishers.

Menzies Lyth, I. (1960). Social systems as a defence against anxiety: an empirical study of the nursing system of a general hospital. Human Relations, 13, 95-121. 
Meyer, A. D. (1982). Adapting to environmental jolts. Administrative Science Quarterly, $27,515-537$.

Miller, E. J. 1993. From dependency to autonomy. London: Free Association Books.

Miller, E. J. \& Gwynne, G. V. (1973). Dependence, independence, and counterdependence in residential institutions for incurables. In R. H. Gosling (Ed.), Support, innovation and autonomy, 67-81. London: Tavistock.

Miller E. J. \& Rice, A. K. 1967. Systems of organization. London: Tavistock.

Morgeson, F. P., Mitchell, T. R., \& Liu, D. (2015). Event system theory: An eventoriented approach to the organizational sciences. Academy of Management Review, 40(4), 515-537.

Nemeth, C., Wears, R., Woods, D., Hollnagel, E. \& Cook, R. (2008). Minding the gaps: Creating resilience in health care. In K. Henriksen, J. B. Battles \& M. A. Keyes (Eds.), Advances in Patient Safety, 1-13. Rockville, MD: AHRQ.

Obholzer, A. (1994). Managing social anxieties in public sector organizations. In A. Obholzer \& V. Z. Roberts (Eds.), The unconscious at work, 187-196. London: Routledge.

Pearson, C. M., \& Clair, J. A. (1998). Reframing crisis management. Academy of Management Review, 23(1), 59-76.

Perrow, C. (2007). The next catastrophe. Princeton NJ: Princeton University Press.

Podolny, J., Khurana, R., \& Hill-Popper, M. (2005). Revisiting the meaning of leadership. Research in organizational behavior, 26, 1-36.

Powley, E. H. (2009). Reclaiming resilience and safety: Resilience activation in the critical period of crisis. Human Relations, 62(9): 1289-1326. 
Reason, J. (1990). Human error. Cambridge UK: Cambridge University Press.

Reason, J. T (1997). Managing the risks of organizational accidents. London: Aldershot.

Rerup, C. (2009). Attentional triangulation: Learning from unexpected rare crises. Organization Science, 20(5), 876-893.

Roberts, K. H., \& Rousseau, D. M. (1989). Research in nearly failure-free, highreliability organizations: Having the bubble. IEEE Transactions on Engineering Management, 36(2), 132-139.

Roberts, K. H., Stout, S. K., \& Halpern, J. J. (1994). Decision dynamics in two high reliability military organizations. Management Science, 40(5), 614-624.

Ross, L. (1977). The intuitive psychologist and his shortcomings: Distortions in the attribution process. In L. Berkowitz (Ed.), Advances in Experimental Social Psychology, 173-220. New York: Academic Press.

Roux-Dufort, C. (2009). The devil lies in details! How crises build up within organizations. Journal of Contingencies and Crisis Management, 17(1), 4-11.

Rudolph, J. W. \& Repenning, N. P. (2002). Disaster dynamics: Understanding the role of quantity in organizational collapse. Administrative Science Quarterly, 47(1), 130.

Shalev, A. Y. \& Errera, Y. (2008) Resilience is the default: How not to miss it. In M. Blumenfield \& R. J. Ursano (Eds.), Intervention and resilience after mass trauma, 149-172. Cambridge: Cambridge University Press.

Sherif, M. (1966). Group conflict and co-operation. London: Routledge Kegan Paul. 
Silbey, S. S. (2009). Taming Prometheus: Talk about safety and culture. Annual Review of Sociology, 35, 341-369.

Staw, B. M., Sandelands, L. E. \& Dutton, J. E. (1981). Threat rigidity effects in organizational behavior: A multi-level analysis. Administrative Science Quarterly, 26(4): 501-524.

Sutcliffe, K. M. \& Vogus, T. (2003). Organizing for resilience. In K. S. Cameron, J. E. Dutton \& R. E. Quinn (Eds.), Positive organizational scholarship, 94-110. San Francisco: Berrett-Koehler.

Sutcliffe, K. M., \& Weick, K. E. (2013). Mindful organizing and resilient health care. In E. Hollnagel, J. Braithwaite \& R. Wears (Eds.), Resilient health care, 145-156. Surrey, UK: Ashgate.

Tajfel, H., \& Turner, J. C. (1979). An integrative theory of intergroup conflict. The Social Psychology of Intergroup Relations, 33(47), 74.

Turner, B. A. (1976). The organizational and interorganizational development of disasters. Administrative Science Quarterly, 21(3), 378-397.

Turner, J. C. (1975). Social comparison and social identity: Some prospects for intergroup behaviour. European Journal of Social Psychology, 5(1), 1-34.

Tversky, A., \& Kahneman, D. (1981). The framing of decisions and the psychology of choice. Science, 211, 453-458.

van Knippenberg, D. (2003). Intergroup relations in organizations. In M. A. West, D. Tjosvold \& K. G. Smith (Eds.), International handbook of organizational teamwork and cooperative working, 381-399. Chichester, England: John Wiley. 
Vogus, T. J., \& Sutcliffe, K. M. (2007). Organizational resilience: towards a theory and research agenda. In 2007 IEEE International Conference on Systems, Man and Cybernetics, 3418-3422). IEEE.

Wageman, R. (1995). Interdependence and group effectiveness. Administrative Science Quarterly, 40(1), 145-180.

Wears, R. L.\& Perry, S. J. (2006). "Free fall”—a case study of resilience, its degradation, and recovery in an emergency department. In E. Rigaud \& E. Hollnagel (Eds.), Second symposium on resilience engineering. Juan-les-Pines, France.

Wears, R. L., Perry, S. J., Anders, S., \& Woods, D. D. (2008). Resilience in the emergency department. Resilience engineering: Remaining open to the possibility of failure, 197-210. Aldershot, UK: Ashgate Publishing.

Weick, K. E. (1976). Educational organizations as loosely coupled systems. Administrative Science Quarterly, 21(1), 1-19.

Weick, K. E. (1988). Enacted sensemaking in crisis situations. Journal of Management Studies, 25(4), 305-317.

Weick, K. E. (1993). The collapse of sensemaking in organizations: The Mann Gulch disaster. Administrative Science Quarterly, 38(4), 628-652.

Weick, K. E. \& Sutcliffe, K. M. (2001). Managing the unexpected. San Francisco: Jossey-Bass.

Weick, K. E., \& Sutcliffe, K. M. (2006). Mindfulness and the quality of organizational attention. Organization Science, 17(4), 514-524.

Westrum, R. (2006). A typology of resilience situations. In E. Hollnagel, D. Woods \& N. Leveson (Eds.), Resilience engineering, 55-65. Burlington, VT: Ashgate. 
Wildavsky, A. (1991). Searching for safety. Transaction, New Brunswick.

Williams, T. A., Gruber, D. A., Sutcliffe, K. M., Shepherd, D. A. \& Zhao, E. Y. (2017). Organizational response to adversity: Fusing crisis management and resilience research streams. Academy of Management Annals, in press.

Woods, D. D. (2006). Essential characteristics of resilience. In E. Hollnagel, D. Woods \& N. Leveson (Eds.), Resilience engineering, 21-34. Burlington, VT: Ashgate.

Woods, D. D., \& Branlat, M. (2011). Basic patterns in how adaptive systems fail. In E. Hollnagel, J. Paries, D. D. Woods \& J. Wreathall (Eds.), Resilience engineering in practice, 127-144. Burlington VT: Ashgate.

Woods, D. D. \& Patterson, E. S. (2000). How unexpected events produce an escalation of cognitive and coordinative demands. In P. Hancock \& P. Desmond (Eds.), Stress workload and fatigue, 290-304. Mahwah NJ: Lawrence Erlbaum.

Woods, D. D., \& Wreathall, J. (2008). Stress-strain plots as a basis for assessing system resilience. In E. Hollnagel, C. Nemeth \& S. Dekker (Eds.), Remaining sensitive to the possibility of failure, 143-158. Aldershot, UK: Ashgate. 
Table 1: Summary of intergroup pathways

\begin{tabular}{|c|c|c|c|}
\hline & Integration & Disavowal & Reclamation \\
\hline $\begin{array}{l}\text { Pathway } \\
\text { definition }\end{array}$ & $\begin{array}{l}\text { Adjoining parts maintain } \\
\text { synchronicity with the focal part, } \\
\text { remaining aware of its gradual } \\
\text { accumulation of strain. Adjoining } \\
\text { parts seek to provide helpful } \\
\text { resources throughout the } \\
\text { accumulation and cessation of } \\
\text { focal part strain. }\end{array}$ & $\begin{array}{l}\text { Adjoining parts remain separate from } \\
\text { the focal part, which is left to its own } \\
\text { struggles. Adjoining parts repudiate } \\
\text { connections to the focal part, actively } \\
\text { (moving away) or passively } \\
\text { (remaining still). They protect scarce } \\
\text { resources and maintain distance as } \\
\text { strain gradually accumulates. }\end{array}$ & $\begin{array}{l}\text { Adjoining parts follow the disavowal } \\
\text { pathway until some condition shifts- } \\
\text { in the organization, within or between } \\
\text { adjoining and focal parts, in leaders- } \\
\text { and adjoining parts shift to join with } \\
\text { the focal part and support its efforts to } \\
\text { regain effective functioning. }\end{array}$ \\
\hline $\begin{array}{l}\text { Adjoining part } \\
\text { accounts }\end{array}$ & $\begin{array}{l}\text { Adjoining parts embrace accounts } \\
\text { that ascribe focal part strain to the } \\
\text { difficulties of the situation, to the } \\
\text { organization, or to other adjoining }\end{array}$ & $\begin{array}{l}\text { Adjoining parts maintain accounts } \\
\text { that blame the focal part (or other } \\
\text { adjoining parts) for its outstripped } \\
\text { capacity, strain, and operational }\end{array}$ & $\begin{array}{l}\text { Adjoining parts initially use blaming } \\
\text { attributions and accounts to justify } \\
\text { withholding resources from the focal } \\
\text { part. Reclamation occurs as adjoining }\end{array}$ \\
\hline
\end{tabular}




\begin{tabular}{|c|c|c|c|}
\hline & $\begin{array}{l}\text { parts. Such accounts enable } \\
\text { adjoining part members to justify } \\
\text { attempts to relieve focal part } \\
\text { strain. }\end{array}$ & $\begin{array}{l}\text { difficulties. These accounts } \\
\text { emphasize the need for adjoining } \\
\text { parts to guard their boundaries and } \\
\text { resources. }\end{array}$ & $\begin{array}{l}\text { parts revise accounts from blaming the } \\
\text { focal part ("you") to blaming the } \\
\text { situation/organization ("us") or other } \\
\text { adjoining parts ("them"). }\end{array}$ \\
\hline $\begin{array}{l}\text { Adjoining part } \\
\text { identifications }\end{array}$ & $\begin{array}{l}\text { Adjoining parts identify as part of } \\
\text { the larger organization, of which } \\
\text { the focal part is a member with } \\
\text { compatible interests. This } \\
\text { identification enables adjoining } \\
\text { parts to remain connected to focal } \\
\text { parts so as to function as } \\
\text { integrated units. }\end{array}$ & $\begin{array}{l}\text { Adjoining parts identify as in-groups, } \\
\text { disavowing the focal part as an } \\
\text { "other." Adjoining parts perceive } \\
\text { their interests as incompatible with } \\
\text { the focal group; such perceptions are } \\
\text { reinforced by cognitive biases such as } \\
\text { confirmation biases and availability } \\
\text { heuristics. }\end{array}$ & $\begin{array}{l}\text { The revised accounts enable adjoining } \\
\text { parts to either annex focal parts, } \\
\text { incorporating them into expanded } \\
\text { identities, or shift from group to } \\
\text { organizational identifications by } \\
\text { joining with focal parts to size up and } \\
\text { develop strategies to handle } \\
\text { accumulating strain. }\end{array}$ \\
\hline $\begin{array}{l}\text { organizational } \\
\text { resilience }\end{array}$ & $\begin{array}{l}\text { The organization is a coherent } \\
\text { system of linked parts across } \\
\text { which flow necessary resources }\end{array}$ & $\begin{array}{l}\text { Parts are fragmented rather than } \\
\text { synchronized, creating multiple } \\
\text { organizations with which members }\end{array}$ & $\begin{array}{l}\text { Adjoining and focal parts are more or } \\
\text { less cohered into a system of linked } \\
\text { parts according to the timing of }\end{array}$ \\
\hline
\end{tabular}




\begin{tabular}{|c|c|c|c|}
\hline & $\begin{array}{l}\text { that enable uniform functioning. } \\
\text { The synchronized efforts of } \\
\text { adjoining and focal parts allow } \\
\text { the organization to effectively } \\
\text { perceive, develop strategies for, } \\
\text { and adapt to potentially disabling } \\
\text { quantities of interruptions and } \\
\text { strain. }\end{array}$ & $\begin{array}{l}\text { from separate parts differentially } \\
\text { identify. This fragmentation impedes } \\
\text { or blocks the flow of resources to the } \\
\text { focal part, which undermines } \\
\text { collective attentional coherence and } \\
\text { leaves the organization brittle and } \\
\text { vulnerable to crises. }\end{array}$ & $\begin{array}{l}\text { reclamation processes. Quicker, } \\
\text { comprehensive reclamations leave the } \\
\text { organization a relatively coherent } \\
\text { whole, such as that created by } \\
\text { integration. Slower, less } \\
\text { comprehensive reclamations degrade } \\
\text { the focal part and leave the } \\
\text { organization fragmented and brittle, } \\
\text { similar to that created by disavowal. }\end{array}$ \\
\hline $\begin{array}{l}\text { Influences that } \\
\text { determine } \\
\text { adjoining part } \\
\text { capacity to } \\
\text { provide help }\end{array}$ & $\begin{array}{l}\text { Adjoining parts have the } \\
\text { resources_-people, technology, } \\
\text { space, ideas, information, } \\
\text { finances, or empathy—necessary } \\
\text { to help the focal part. Adjoining } \\
\text { parts are also relatively }\end{array}$ & $\begin{array}{l}\text { Adjoining parts lack the resources- } \\
\text { people, technology, space, ideas, } \\
\text { information, finances, or empathy- } \\
\text { necessary to help the focal part. Or } \\
\text { adjoining parts have become a focal } \\
\text { part, suffering enough strain as to }\end{array}$ & $\begin{array}{l}\text { Adjoining parts may initially lack the } \\
\text { resources_-people, technology, space, } \\
\text { ideas, information, finances, or } \\
\text { empathy_-necessary to help the focal } \\
\text { part, but then have slack resources } \\
\text { become available, recoverable, or }\end{array}$ \\
\hline
\end{tabular}




\begin{tabular}{|c|c|c|c|}
\hline & $\begin{array}{l}\text { unaffected by their own strain; } \\
\text { their operations and resources are } \\
\text { healthy enough to sustain the } \\
\text { helping of the focal part. }\end{array}$ & $\begin{array}{l}\text { have compromised their own } \\
\text { operations and resources. They } \\
\text { disavow as a form of self- } \\
\text { preservation. }\end{array}$ & $\begin{array}{l}\text { developed. Or the strain that degrades } \\
\text { adjoining parts is relieved, enabling } \\
\text { them to recover operations and bring } \\
\text { resources to help the focal part. }\end{array}$ \\
\hline $\begin{array}{l}\text { Influences that } \\
\text { facilitate or } \\
\text { undermine } \\
\text { adjoining part } \\
\text { willingness to } \\
\text { provide help }\end{array}$ & $\begin{array}{l}\text { Adjoining and focal parts are } \\
\text { interdependent, tightly coupled in } \\
\text { daily operations; their history is } \\
\text { positive, marked by previous } \\
\text { instances of integration or quick } \\
\text { reclamation; and their relative } \\
\text { power facilitates adjoining part } \\
\text { willingness to help the focal part. }\end{array}$ & $\begin{array}{l}\text { Adjoining and focal parts are too } \\
\text { loosely coupled in daily operations; } \\
\text { their history is mostly negative, } \\
\text { marked by previous instances of } \\
\text { disavowal or slow, degrading } \\
\text { reclamation; or their relative power } \\
\text { status undermines adjoining part } \\
\text { willingness to help the focal part. }\end{array}$ & $\begin{array}{l}\text { Loosely coupled adjoining and focal } \\
\text { parts become more tightly coupled in } \\
\text { daily operations; their history is } \\
\text { positive enough to enable shifts from } \\
\text { disconnection to connection; or their } \\
\text { relative power shifts or relaxes enough } \\
\text { to facilitate adjoining part willingness } \\
\text { to help the focal part. }\end{array}$ \\
\hline
\end{tabular}




\section{Page 53 of 55}

\section{Academy of Management Review}

32

33

34
35

36

37

38
39

40

41

44

45

49 
William A. Kahn (wkahn@bu.edu) is professor of organizational behavior at Boston University Questrom School of Business. He received his Ph.D. in psychology from Yale University. His current research examines the nature of relationships within and between groups under conditions of emotional complexity in organizations.

Michelle A. Barton (mbarton@, bu.edu) is an assistant professor of organizational behavior at Boston University Questrom School of Business. She received her Ph.D. from the University of Michigan. Her research focuses on how groups manage uncertain events as they are unfolding, with an emphasis on resilience within and during extreme contexts.

Colin M. Fisher (colin.fisher@ucl.ac.uk) is an assistant professor of organizational behavior at University College London. His research deals with collaboration and temporal dynamics (i.e., timing, rhythm, development over time) in three areas: leading, helping, and coaching teams; collective creativity and improvisation; and group decisionmaking and negotiations.

Emily D. Heaphy (eheaphy@uri.edu) is an assistant professor at the University of Rhode Island. She received her $\mathrm{PhD}$ from the University of Michigan. Her research examines social relationships, emotions and the human body at work.

Erin M. Reid (reidem@mcmaster.ca) is an associate professor of human resources and management at McMaster University. She received her PhD from Harvard University. She studies the interrelations between identity, how work is organized, and the careers that men and women pursue.

Elizabeth D. Rouse (rouse@bu.edu) is an assistant professor of organizational behavior at Boston University Questrom School of Business. She received her PhD from Boston College. Her research focuses on collaboration at work, creative processes, and how creative workers psychologically attach to and detach from the products they make. 

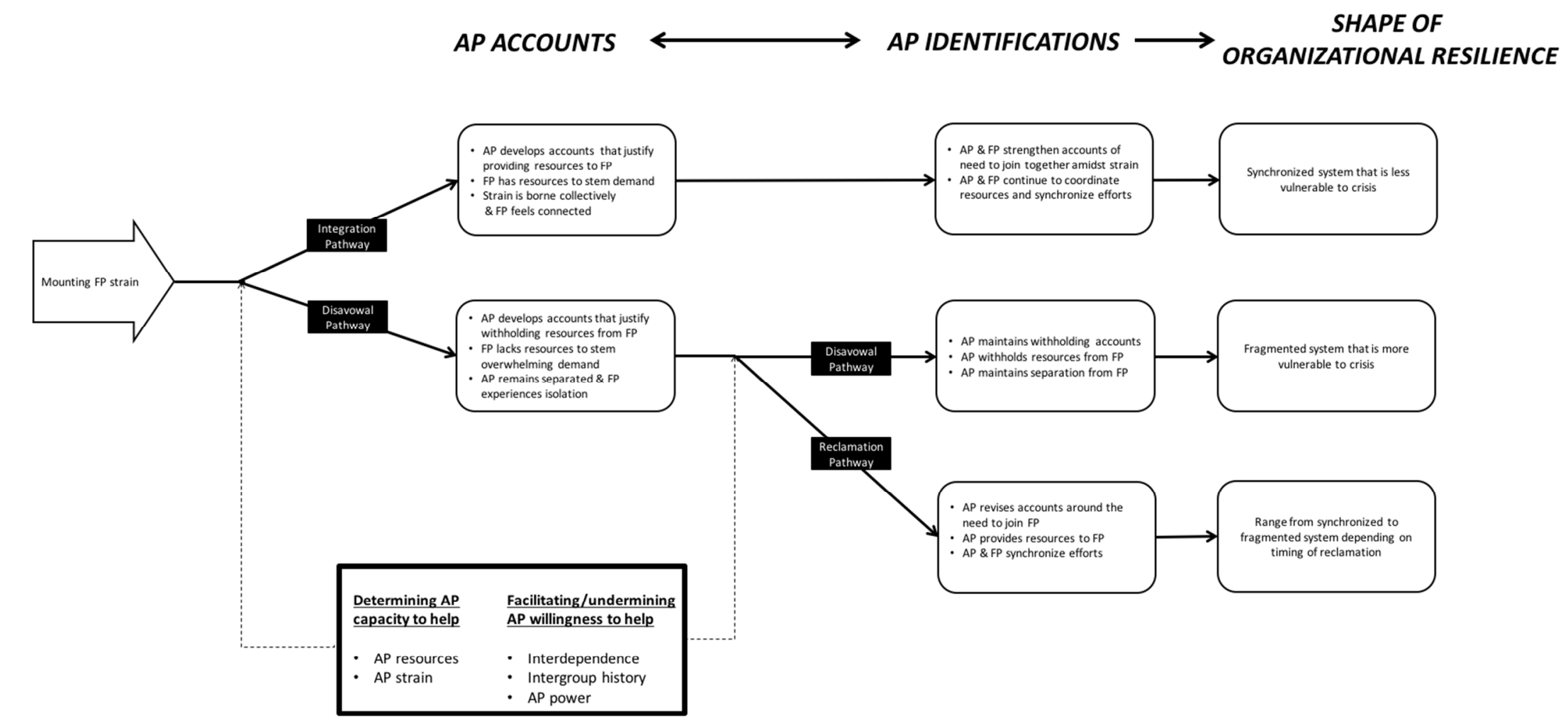

Key:
FP: Focal part

FP: Focal part
AP: Adjoining part 